\title{
First stages towards the establishment of Brazilian neurology faculties
}

\author{
Primeiros passos das escolas de neurologia do Brasil \\ Alex Tiburtino MEIRA', Beatriz Gioppo BETINI', Francisco CARDOSO², Marleide da Mota GOMES ${ }^{3}$, Egberto \\ Reis BARBOSA4, Roberto César Pereira do PRADO55, Hélio Afonso Ghizoni TEIVE ${ }^{1}$
}

\begin{abstract}
The establishment of modern medicine in Brazil was marked by the arrival of the Portuguese Court in 1808, when the Bahia and Rio de Janeiro Faculties of Medicine were founded. The French School of Medicine exerted a strong influence on Brazilian medicine and on the main pioneers of Brazilian neurology. The elite of "Parisian neurology" trained students and doctors from around the world, and were mentors to the pioneers of Brazilian neurology in the early $20^{\text {th }}$ century. In this article, the authors review the origins of neurology faculties in Brazilian medicine and the main pioneers of Brazilian neurology. Neurology is certainly a continuously changing field and has always adapted to new advances and discoveries, and it is an honor for the authors to pay homage to their pioneers.
\end{abstract}

Keywords: Schools, medical; neurology; history.

\section{RESUMO}

O estabelecimento da medicina moderna no Brasil foi marcado pela chegada da corte portuguesa em 1808, quando foram fundadas as faculdades de medicina da Bahia e do Rio de Janeiro. A Escola Francesa de Medicina exerceu forte influência na Medicina Brasileira e nos principais pioneiros da Neurologia Brasileira. A elite da "Neurologia parisiense", treinou estudantes e médicos de todo o mundo e foram os mentores dos pioneiros da neurologia brasileira no início do século XX. Neste texto, os autores revisam as origens das faculdades de Neurologia na Medicina Brasileira e os principais pioneiros da Neurologia Brasileira. A neurologia é certamente um campo em constante mudança e sempre se adaptou a novos avanços e descobertas, e é uma honra para os autores homenagear seus pioneiros.

Palavras-chave: Faculdades de medicina; neurologia; história.

The study of anatomy and physiology of the nervous system became widespread during the $19^{\text {th }}$ century. This was mainly due to the anatomo-clinical method of study, which correlated what neurologists had previously observed at the bedside with autopsy findings, and led to the establishment of the French, German and English schools of medicine, which were largely responsible for the basis of modern neurology $y^{1,2}$. Famous names in the history of medicine, such as Philippe Pinel (1745-1826), Rene-Theophile-Hyacinthe Laennec (17811826), François-Joseph-Victor Broussais (1772-1838) and the forefathers of neurology in France, Guillaume B.A. Duchenne (1806-1875) and Jean-Martin Charcot (1825-1893) were renowned for adopting the anatomo-clinical method in their lectures and practice ${ }^{2}$.

At the beginning of the $19^{\text {th }}$ century, there was considerable overlap between neurology and psychiatry, but at the Salpêtrière Hospital, in Paris, through the work of Charcot and his many disciples, the two merged into a single and separate specialty in internal medicine. These neurologists provided clinical and pathological descriptions of several neurological diseases, such as multiple sclerosis, amyotrophic lateral sclerosis, hereditary motor and sensory neuropathy, and motor ataxia ${ }^{2,3,4}$. However, it was only in 1882 , when Charcot became the first Professor of Neurology at the Faculty of Medicine

\footnotetext{
${ }^{1}$ Universidade Federal do Paraná, Hospital de Clínicas, Departamento de Medicina Interna, Serviço de Neurologia, Curitiba PR, Brasil;

${ }^{2}$ Universidade Federal de Minas Gerais, Hospital das Clínicas, Departamento de Medicina Interna, Serviço de Neurologia, Belo horizonte MG, Brasil;

${ }^{3}$ Universidade Federal do Rio de Janeiro, Departamento de Neurologia, Rio de Janeiro RJ, Brasil;

${ }^{4}$ Universidade de São Paulo, Hospital das Clínicas, Serviço de Neurologia, Ambulatório de Distúrbios do Movimento, São Paulo SP, Brasil;

${ }^{5}$ Universidade Federal de Sergipe, Departamento de Neurologia, Aracajú SE, Brasil.
}

AlexT. Meira (iD) https://orcid.org/0000-0002-6685-7491; Beatriz Gioppo Betini iD https://orcid.org/0000-0002-3714-6471; Francisco Cardoso https://orcid.org/0000-0003-0808-0116; Marleide da Mota Gomes iD https://orcid.org/0000-0001-8889-2573; Hélio Afonso Ghizoni Teive iD https://orcid.org/0000-0002-4045-1178

Correspondence: Hélio A. G. Teive; Rua General Carneiro, 1103/102, Centro; 80060-150 Curitiba PR, Brasil; E-mail: hagteive@mps.com.br

Conflict of interest: There is no conflict of interest to declare.

Received 06 April 2019; Received in final form 09 June 2019; Accepted 17 June 2019. 
of the University of Paris, that neurology was established as an independent medical specialty. At that point, the French school became famous throughout the world ${ }^{2}$.

Pierre Marie, Babinski, Guillain, and Dejerine, all members of the "Parisian neurology" elite, trained students and doctors from around the world, and were mentors to the pioneers of Brazilian neurology in the early $20^{\text {th }}$ century. Also included as founders of Brazilian neurology schools were Antônio Austregésilo Rodrigues de Lima (1876-1960), Aloysio de Castro (1881-1959), Enjolras Vampré (1895-1938), and Deolindo Augusto de Nunes Couto (1902-1992) 2,5. Moreover, the French School of Medicine had a profound influence on the first pioneers of Brazilian Neurology, such as José Martins da Cruz Jobim (1802-1878), João Vicente Torres Homem (1837-1887), as well as the alienist specialist in mental illness, João Carlos Teixeira Brandão (1854-1921).

\section{NEUROLOGY IN BRAZIL}

In Brazil, the establishment of modern medicine was heralded by the arrival of the Portuguese Court in 1808. In the same year, Dom João VI founded the Bahia and Rio de Janeiro faculties of medicine, and the former colony became the seat of the Portuguese Empire. European medicine spread and was adapted to the still-provincial country. Several key measures were taken to improve both medical and academic competence, primarily in the first capital cities in the country, Salvador and Rio de Janeiro, followed by other towns and cities of political and economic significance ${ }^{3,4}$.

In 1898, soon after the country was proclaimed a republic, the third Brazilian medical school was established, at the Federal University of Rio Grande do Sul. Following this, other medical faculties were founded in other states - Minas Gerais (1911), Paraná and São Paulo (1912), Pará (1919), and Pernambuco $(1920)^{3,4}$.

As previously mentioned, the French School of Medicine exerted a strong influence on Brazilian medicine and on the main pioneers of Brazilian neurology. Among the first in this area, José Martins da Cruz Jobim graduated in medicine at the Faculté de Médecine de Paris (1828) and was strongly influenced by the theories of the physician François Broussais. As the author of the first study that adopted a neuropsychiatric approach, Insania Loquaz (1831), Jobim is regarded as the first Brazilian neuropsychiatrist. João Vicente Torres Homem was the author of the first Brazilian medical book devoted entirely to neurology: Lições sobre as moléstias do systema nervoso feitas na faculdade de medicina do Rio de Janeiro [Lectures on disorders of the nervous system delivered at the Faculty of Medicine, Rio de Janeiro]
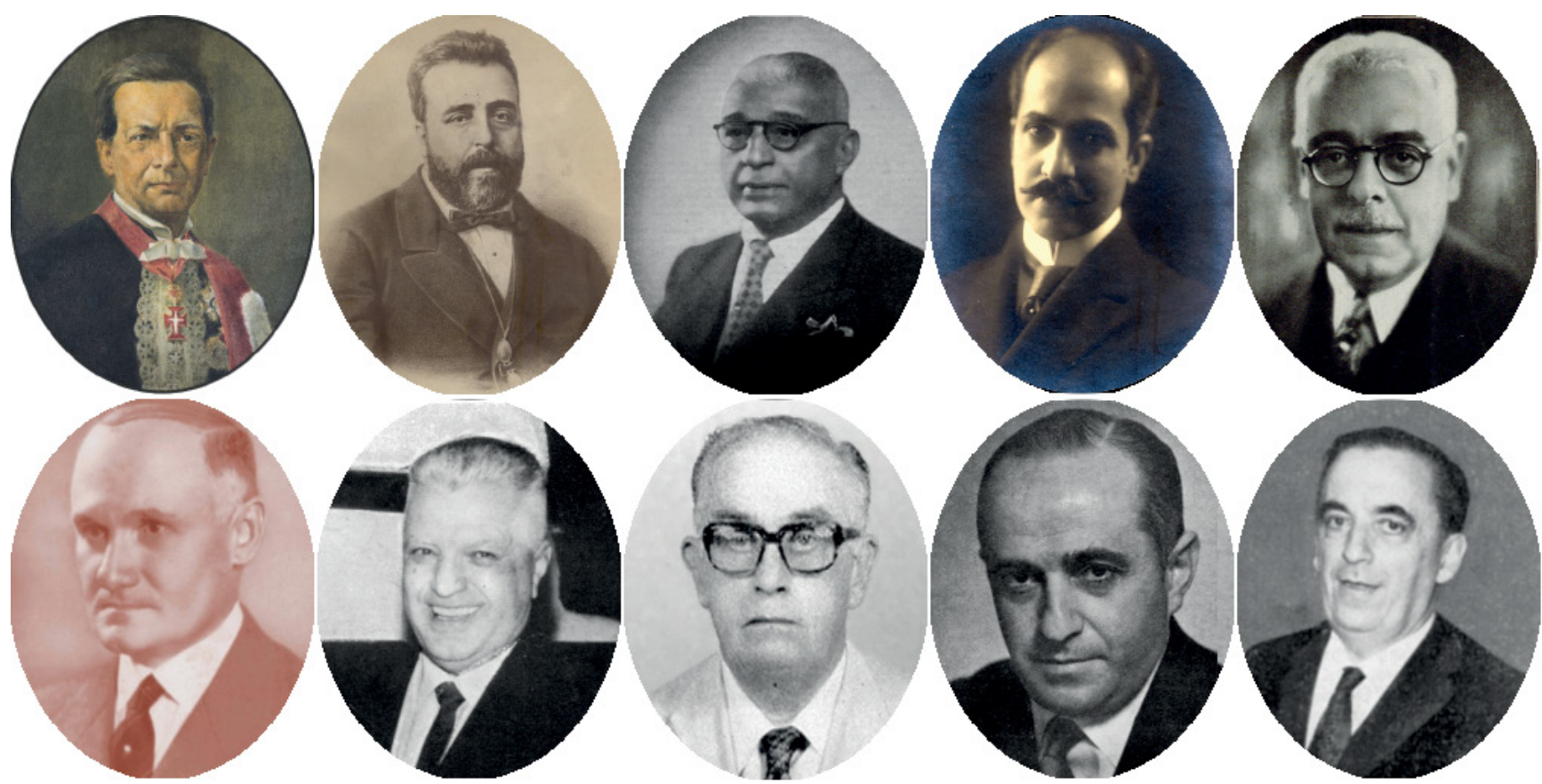

Figure 1. Beginnings of Neurology in Brazil. From left to right, top row: 1. José Martins da Cruz Jobim (1802-1878); 2. João Vicente Torres Homem (1837-1887); 3. Antônio Austregésilo Rodrigues de Lima (1876-1960); 4. Aloysio de Castro (1881-1959); 5. Enjolras Vampré (1895-1938). From left to right, bottom row: 6. Deolindo Augusto de Nunes Couto (1902-1992); 7. Adherbal Tolosa (18991973); 8. Oswaldo Lange (1903-1986); 9. Paulino Watt Longo (1903-1967); 10. Paulo Pinto Pupo. 1, 2, 4, 5 and 6: http://www. anm.org.br; 3. Ao professor Antônio Austregésilo. Arquivos de Neuro-Psiquiatria 1945; 3 (2): 117-120; 7. Teive, Hélio A. Ghizoni, \& Caramelli, Paulo. Arquivos de Neuro-Psiquiatria: 75 years. Arquivos de Neuro-Psiquiatria. 2018; 76(1): 50-52; 8. Lange, 0. Prof. Adherbal Pinheiro Machado Tolosa: homenagem pelo $70^{\circ}$ aniversário natalício. Um mestre. Arquivos de Neuro-Psiquiatria 1969; 27 (4): 9. Lange, O. In memoriam. Arquivos de Neuro-Psiquiatria 1967; 25 (4): 316-317; 10. Lange, O. Professor Paulo Pinto Pupo 1911-1970. Arquivos de Neuro-Psiquiatria 1970; 28 (3): 303-305. 


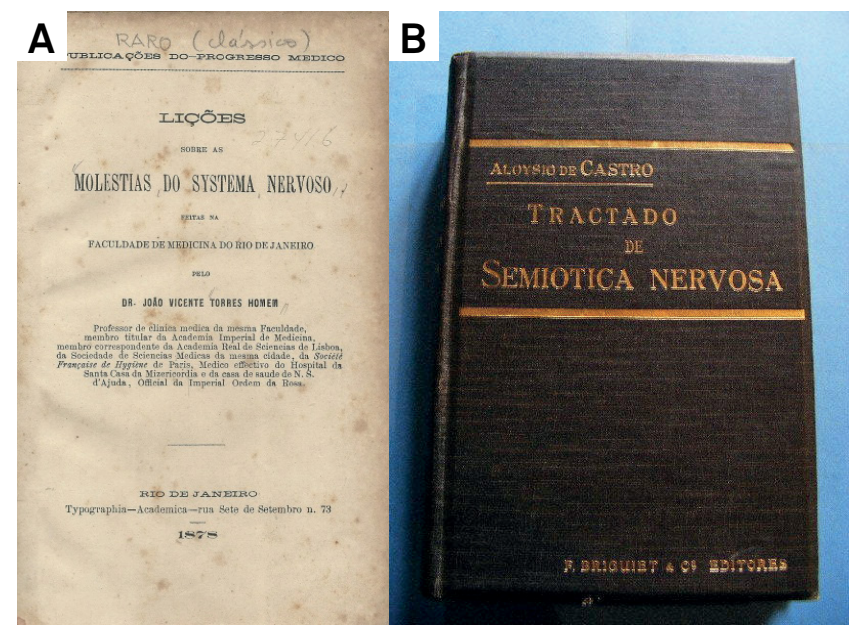

Figure 2. Two of the three pioneering works in the neurology literature in Brazil. A. Lições sobre as moléstias do systema nervoso feitas na Faculdade de medicina do Rio de Janeiro (João Vicente Torres Homem - 1878). B. Tractado de semiotica nervosa (Aluysio de Castro - 1914). Extracted from: A: http://www.babelleiloes.com.br/peca.asp?ID=2764957; B: https://www.discounts-exclusive. top/br\%C3\%A9sil-aloysio-de-castro-tractado-de-semiotica-nervosa-editions-breguiet-1914-p-9140.html.

(1878 - Figure 2A). He was a professor at the Faculty of Medicine of Rio de Janeiro and considered to be the greatest figure in Brazilian medicine in the $19^{\text {th }}$ century and, by some, of all time ${ }^{3}$. The Table shows the key milestones that marked the beginning of Brazilian neurology.

\section{NEUROLOGY IN RIO DE JANEIRO}

Nervous and mental diseases were officially recognized by the Brazilian government as a branch of medical science in 1882 (as enacted in Decree No. 3141), and this was of crucial importance in establishing the subjects of neurology and psychiatry, which were practiced at the same time ${ }^{3}$.

The practice of neurology began at the National Hospice for the Insane, at the Holy House of Mercy, Rio de Janeiro, as well as the Rio de Janeiro General Polyclinic. Neuropsychiatric practice was common at that time. Juliano Moreira (1873-1933), of German biological psychiatric influence, the founder of Brazilian scientific psychiatry and director of the National Hospice for the Insane, was influenced by German biological theories and João Carlos Teixeira Brandão, of French alienist influence, was the first professor of the Department of Nervous and Mental Diseases. These two physicians were influenced by the study of mental disorders, which were essential to the foundation of Brazilian neurology $y^{3,4}$.

Until 1911, the study of neurology was a part of clinical medicine and psychiatry. The formal beginning of the study as a separate specialty dates from 1912, with the creation of the chair of the Department of Neurology at the Faculty of Medicine of Rio de Janeiro, with Prof. Antônio Austregésilo being appointed as the first incumbent of this post ${ }^{6}$. He is regarded as the "father" of modern Brazilian neurology and he published several papers on psychology and neurology, especially regarding the study of movement disorders and even hysteria. In addition, Austregésilo was responsible for implementing neurosurgery in Brazil, and established neurology at the same place where, 16 years later, the first Brazilian Neurological Institute would be founded ${ }^{1,6}$. He was also the custodian of the Brazilian Medical Archives and the Brazilian Archives of Neurology and Psychiatry. As well as approaching academic work as a practice, Austregésilo was a writer and essayist, a member of the Brazilian Academy of Letters and a representative of the Symbolists ${ }^{3,4,6}$.

Aloysio de Castro graduated in 1903 at the Faculty of Medicine, Rio de Janeiro. After graduating, he improved his skills in nervous semiology at the Hôpital Bicêtre in Paris, under the guidance of Pierre Marie (1853-1940). After his return to Brazil, he worked at the General Polyclinic of Rio de Janeiro and collected a large number of photographs and films depicting gaits, involuntary movements and other neurological stances, when preparing his first book on nervous semiotics entitled Tractado de semiotica nervosa [Treatise on the Semiotics of the Nervous System] (1914 -Figure 2). This work was revolutionary, as it was the first time that photography was used as a teaching tool ${ }^{3,4,6}$. Although Prof. Aloysio de Castro was fluent in other languages including French and English, his thesis and books were only published in Portuguese. This meant that his work did not earn the international respect it deserved ${ }^{3,4,7}$.

Faustino Monteiro Esposel (1888-1931) graduated in 1910 at the Faculty of Medicine, Rio de Janeiro, and was the successor to Antonio Austregésilo. In 1912, Esposel published in the journal L'Encéphale [The Brain] an article entitled "Le phénomène de Babinski, provoqué par l'excitation de la cuisse" [The Babinski phenomenon provoked by pressure on the thigh] describing one of the variants of the Babinski "sign" 3, . 
Table. Milestones of Brazilian Neurology: 1831 to 1964.

\begin{tabular}{|c|c|}
\hline 1831 & $\begin{array}{c}\text { Publication of Insania loquaz (1835), by one of the pioneers of neuropsychiatry in Brazil, José Martins da Cruz Jobim, the first } \\
\text { publication about mental illness in Brazil. }\end{array}$ \\
\hline 1852 & Inauguration of the D. Pedro II Hospice. \\
\hline 1867 & João Carlos Teixeira Brandão appointed director of D. Pedro II Hospice. \\
\hline 1878 & $\begin{array}{l}\text { Publication of the first Brazilian book on neurology: Lessons about the disorders of the nervous system (João Vicente Torres } \\
\text { Homem). }\end{array}$ \\
\hline 1881 & Foundation of the General Polyclinic of Rio de Janeiro. \\
\hline $1882 *$ & Creation of the chair of Mental Diseases (Law n 3.141, October 30, 1882). \\
\hline 1883 & $\begin{array}{c}\text { First public competition for the chair of Nervous and Mental Diseases, at the Faculty of Medicine of Rio de Janeiro. João Carlos } \\
\text { Teixeira Brandão was the winner. }\end{array}$ \\
\hline 1886 & $\begin{array}{l}\text { Second public competition for the specialist field, in the Faculty of Medicine of Bahia, Augusto Freire de Maia Bittencourt was } \\
\text { the winner (1886-1891). }\end{array}$ \\
\hline 1890 & The D. Pedro II Hospice is now called the National Hospice of the Injured and is separate from the Holy House of Mercy. \\
\hline 1898 & Inauguration of the Juqueri Hospital, in São Paulo, under the directorship of Francisco Franco da Rocha. \\
\hline 1903 & Juliano Moreira is appointed the director of the National Hospice of the Injured, a post he held until 1930. \\
\hline 1905 & Juliano Moreira began editing the Brazilian Archives of Psychiatry, Neurology and Legal Medicine. \\
\hline 1907 & Founding, (in Rio de Janeiro), of the Brazilian Society of Psychiatry, Neurology and Legal Medicine. \\
\hline 1912 & Neurology became an independent medical specialty at the Rio de Janeiro medical school. \\
\hline 1914 & $\begin{array}{l}\text { Aloysio de Castro published Tractado de Semiotica Nervosa. } \\
\text { Luiz Pinto de Carvalho was appointed to the second chair of Neurology in Brazil, at the Faculty of Medicine, Bahia. }\end{array}$ \\
\hline 1915 & Official division of the chairs of Psychiatry and Neurology (Decree n⿳0 11.530, 1915, art. 42). \\
\hline 1925 & Enjolras Vampré appointed to the chair of Neurological and Psychiatric Clinic of the Faculty of Medicine of São Paulo. \\
\hline 1935 & $\begin{array}{l}\text { Aloysio de Castro published Semiotica Nervosa. } \\
\text { Enjolras Vampré assumed the chair of Neurology at the Faculty of Medicine of São Paulo. }\end{array}$ \\
\hline 1938 & $\begin{array}{l}\text { Adherbal Tolosa replaced Enjolras Vampré, who died prematurely. } \\
\text { Ulysses Pernambucano was appointed a full professor of the Neurological Clinic of the Faculty of Medicine of Pernambuco. } \\
\text { Ulysses Pernambucano published the Neurobiologia magazine. }\end{array}$ \\
\hline 1943 & Osvaldo Lange, Adherbal Tolosa and Paulino Watt Longo founded the Archives of Neuro-Psychiatry. \\
\hline 1945 & Deolindo Couto assumed the chair of Neurology at the Faculty of Medicine of the University of Brazil. \\
\hline 1946 & Foundation of the first Institute of Neurology in Brazil (by Deolindo Couto). \\
\hline 1962 & Foundation of Brazilian Academy of Neurology (patron Deolindo Couto). \\
\hline 1964 & First Brazilian Neurology Congress. \\
\hline
\end{tabular}

The first institute of neurology was created in Rio de Janeiro (Figure 3), in 1946, by Deolindo Couto. In 1972, the name was changed to the Deolindo Couto Institute of Neurology, in his honor. Its building was situated on the grounds of the former National Hospice for the Insane. Its construction was not a financial burden to the university because it was built through funds obtained by the renowned "prince of Brazilian neurology", Deolindo Couto. At that time, it was considered to be the Brazilian mecca of neurology ${ }^{3}$. It is worth drawing attention to the fact that the origins of Brazilian neurology and psychiatry can be traced back to the grounds of the National Hospice for the Insane, which today are managed by the Federal University of Rio de Janeiro ${ }^{4}$.

The economic decline of the First Brazilian Republic and the changes in society and the economy caused by the period of industrialization stimulated the emergence of new schools and academic leaders in neurology. Hence, there was a second wave of neurological schools in Bahia, Rio Grande do Sul, Minas Gerais, São Paulo, Paraná and Pernambuco, which are briefly described here, together with their most prominent leaders ${ }^{3,4}$.

\section{NEUROLOGY IN BAHIA}

The Faculty of Medicine, Bahia, was founded in 1808, under the influence of Correia Picanço, and its name was changed to the School of Surgery, Bahia, shortly after the arrival of Dom João VI in the country. Psychiatry had a promising start there. Augusto Freire Maia Bittencourt was the first professor of Nervous and Mental Diseases (1886-1891). Luiz Pinto de Carvalho succeeded him as the second chair of Neurology in Brazil in 1914, which was later occupied by Alfredo de Couto Britto in 1925. Important names in Brazilian neurology formed a part of the history of this faculty (Juliano Moreira, Enjolras Vampré and Deolindo Couto) and have been of great significance in several historical periods in Brazil ${ }^{8,9}$. 


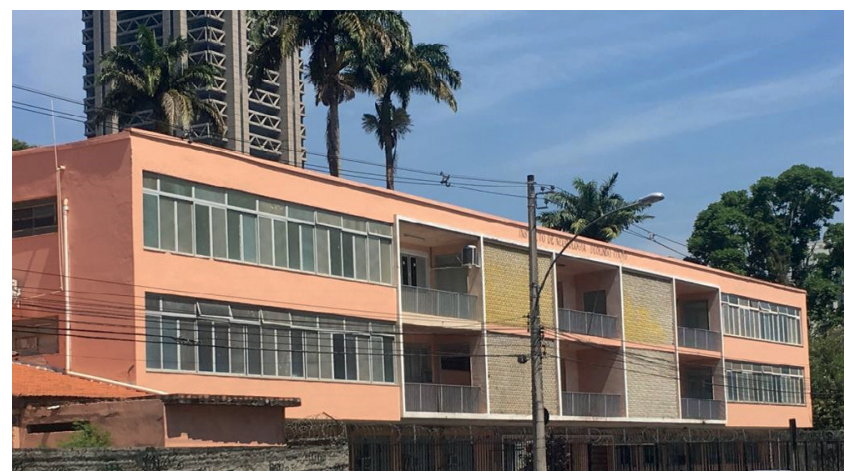

Figure 3. Institute of Neurology in Brazil. The first Institute of Neurology in Brazil, located in Rio de Janeiro, and founded in 1946, by Deolindo Couto. Source: photograph by the authors (MMG).
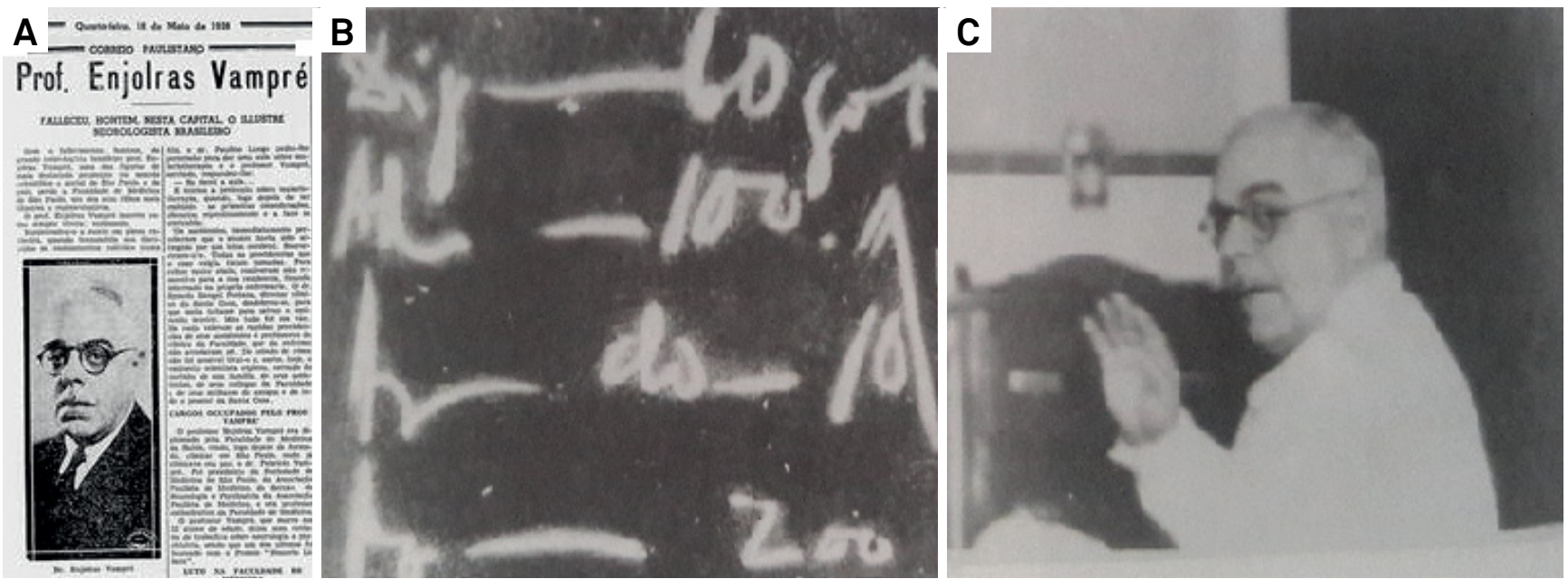

Figure 4. Professor Enjolras Vampré. On May 17, 1938, Enjolras Vampré suffered a severe stroke, and died at the age of 53. A. Article from the Correio Paulistano on the day of his death; B. Photo of his last lecture showing the blackboard immediately after he suffered the stroke; C. Photo of his last lecture moments before the stroke.

\section{NEUROLOGY IN SÃO PAULO}

The Department of Neurology at the Faculty of Medicine, University of São Paulo, originated from the Psychiatric Clinic and Center of Nervous Diseases, created in 1918, and its first director was the psychiatrist Dr. Francisco Franco da Rocha. At first, the classes were given in the Juquerí Hospital, at the Dementes de Perdizes Retreat and as well as at the Laboratory of Pathological Anatomy at the Santa Casa de Misericórdia de São Paulo. In March 1925, Dr. Enjolras Vampré was appointed as the chair of the faculty. While, in 1932, the chair was divided between psychiatry and neurology, he became the head of the latter ${ }^{10}$.

Born in Laranjeiras, São Paulo in 1885, and an honors graduate from the Faculty of Medicine, Bahia, Enjolras Vampré (Figure 4) is seen as the father of neurology in São Paulo, which was the second most important neurological school in Brazil at that time. He was the director of the Hospice of Juquerí (São Paulo), published more than a hundred scientific papers, founded and ran the Paulista Association of Medicine, presided over the Academy of Medicine of São Paulo, and was a member of the National Academy of Medicine, among other entities ${ }^{10,11}$.

During visits to Europe, Vampré attended lessons given by Babinski, Dejerine, Foix, and Bertrand, visited the psychiatric services of Dalldorf, Wuhlgarten, Herzberg and Brechand, and qualified as a neurologist at the Salpêtrière Hospital under the supervision of George Guillain ${ }^{2,10,11}$.

Dr. Vampré was an outstanding personality. Owing to his brilliant teaching ability and great interest in neurological semiology, he was able to influence his assistants and students with his enthusiasm for his profession and his strong desire to keep making progress ${ }^{10,11}$.

His first assistants were Adherbal Tolosa (1899-1973), Paulino Watt Longo (1903-1967) and Oswaldo Lange (1903-1986). The discipline of neurology, which was at first affiliated with the psychiatric clinic, was only established in 1935, and Dr. Vampré was appointed as chair professor. On May 17, 1938, Prof. Dr. Vampré died after suffering a stroke during a class (Figure 4). In that same year, Prof. 
Tolosa replaced him as chair of the Neurological Clinic and Dr. Lange and Dr. Carlos Gama became voluntary faculty, teaching neurology $y^{3,10,12}$.

The Escola Paulista de Medicina (Paulista School of Medicine, São Paulo), founded in 1933, saw Fausto Guerner (1903-1938) as its first professor of neurology. He was a disciple of Prof. Antonio Austregésilo and, later, one of Vamprés volunteer assistants, but he died prematurely in 1938. Paulino Longo replaced Guerner. Longo was a prolific author (with over 250 publications) and trained many neurologists at the Paulista School of Medicine. In February 1967, he retired and died of a stroke in September of that year. His successor was Prof. Paulo Pinto Pupo (1911-1970), who worked with Vampré and Longo. He became the main scientific advisor to Prof. Longo, at the Paulista School of Medicine. Pupo was also the pioneer of electroencephalographic studies in Brazil. He traveled to the USA and Canada to pursue this specialist field, and set up the first EEG machine in Brazil ${ }^{11}$.

It is a remarkable fact that the Arquivos de Neuro-Psiquiatria was founded by Oswaldo Lange, Adherbal Tolosa and Paulino Watt Longo, in 1943. Lange concluded his studies in medicine at the University of São Paulo. In 1962, together with Paulo Pinto Pupo, he wrote the first statute (general rules) for the Brazilian Academy of Neurology. In 1943, the first edition of Arquivos de Neuro-Psiquiatria was published, initially edited by Oswaldo Lange ${ }^{11,13}$.

Another significant event was the foundation of Brazilian Academy of Neurology on May 5, 1962, at the Institute of Neurology. This was undertaken by 53 leading neurologists of that period, including Tolosa, Lefèvre, Deolindo Couto-the leader and host of the inaugural session-, Canelas, Longo, Lange, Pupo, and others. Adherbal Tolosa was the first president (1962-1964), Pinto Pupo (secretary) and Canelas (treasurer). The first scientific meeting was in Curitiba, in 1963, and the first congress held in Ribeirão Preto, in 1964. Deolindo Couto was the second president of the academy (1964-1966) and he created the association's emblem ${ }^{3,4,14}$.

The Santa Casa de Misericórdia Hospital, in São Paulo, founded in 1884, was the first truly academic hospital in the state, prior the foundation of the Hospital das Clínicas and Hospital São Paulo, and it was there that students from the University of São Paulo and the Paulista School of Medicine performed their practical internship rotation. In 1913, the first medical classes began at the Faculty of Medicine and Surgery, São Paulo. However, the Faculty of Medical Sciences of the Holy House of Mercy, São Paulo was founded only in 1962. It was at this same hospital where Prof. Egas Moniz (1874-1955), winner of the Nobel prize in Physiology and Medicine in 1949, performed and taught about the cerebral angiogram ${ }^{15,16}$.

As well as the capital São Paulo, there are several towns and cities in the interior of the country that have important medical schools. Ribeirão Preto, Campinas and Botucatu are some examples with their respective universities: University of São Paulo (Ribeirão Preto), State University of Campinas (São Paulo) and State University of São Paulo (Botucatu).

The Department of Neurology was created, and run by Paulo Pinto Pupo, in 1956, at the University of São Paulo, Ribeirão Preto. He was aided by Mario Martinez, and invited to the cerebrospinal fluid laboratory by Isnard de Reis Filho. In 1958, Jorge Armbrust de Lima Figueiredo replaced Pupo, and many other changes took place in the department over the following years. The residency in neurology was created in 1961, together with the creation of a neurology ward to provide this service. It was in this city, in 1964, that the Brazilian Academy of Neurology's first Brazilian Congress of Neurology took place, under the chairmanship of Jorge Armbrust Figueiredo ${ }^{17}$.

The Faculty of Medical Sciences of the State University of Campinas had its first contest for the chair of neurology in 1966. Dr. Zeferino Vaz (coordinator), together with Paulo Romeo and Antonio Augusto de Almeida formed the panel of appraisers. Oswaldo Freitas Julião was chosen as the first professor, after beating José Antonio Levy; both were professors at the University of São Paulo. The winner, a disciple of Vampré and Adherbal Tolosa, had been an associate professor of neurology at the Faculty of Medicine of the University of São Paulo since 1945, with internships in the USA and Europe. Oswaldo had trained for a long time in the Department of Neurology of Prof. Raymond Garcin, at the Salpêtrière Hospital (Paris). He published Systematization of the Neurological Exam, in three editions (1943, 1945 and 1952) $)^{3,18}$.

The Faculty of Medical and Biological Sciences of Botucatu was created in 1963, and incorporated into the State University of São Paulo, Botucatu in 1976. The discipline of neurology was initially a part of the Department of Clinical Medicine and was taught by the external professor Antônio Spina França. He was then replaced by Prof. Jeova Barros da Silva in the Department of Neurology. The Department of Neurology, Psychology and Psychiatry was set up in 1972, with Antônio Spina França Netto and Jeova Barros da Silva as its professors of neurology $y^{3,18}$.

\section{NEUROLOGY IN MINAS GERAIS}

The Medical School of Belo Horizonte, later renamed the Federal University of Minas Gerais School of Medicine, was founded on March 5, 1911. One of the founders was Alfredo Balena (1882-1949), professor of Internal Medicine, and its dean from 1920 until his death. Despite being an internist, he was the author of the first neurological studies in Minas Gerais: Epilepsia Endócrina [Endocrine Epilepsy] (1924) and Novo Processo Therapeutico da Choréa de Sydenham [A New Therapeutic Treatment of Sydenham's Chorea] $(1926)^{1}$. Initially, neurology in Minas Gerais was 
practiced by following the German model of neuropsychiatry. Álvaro Ribeiro de Barros (1879-1922), the first professor of Neurology (1914) in Minas Gerais, was also the director of the Institute of Neuropsychiatry of Belo Horizonte, now called the Instituto Raul Soares. He was succeeded as professor of Neurology and director of the Institute of Neuropsychiatry by Washington Ferreira Pires (1892-1970), who graduated in Rio de Janeiro where he was an assistant to Miguel Couto (1865-1934) ${ }^{19}$. Despite being a neuropsychiatrist, Pires' main interest was in politics. He was a member of the lower house of the Brazilian parliament and became the Minister of Education and Health ${ }^{20}$. His political activities led him to spend long periods away, particularly in Rio de Janeiro. The neuropsychiatrists who were disciples of Pires, and one of his assistants, Caio Líbano de Noronha Soares (1904-1991), practiced neurology in Minas Gerais until a new era was ushered in by José Geraldo Albernaz (1923-2015). Albernaz graduated from the Federal University of Minas Gerais School of Medicine and trained as a neurologist and neurosurgeon at Illinois University under the supervision of Paul Bucy and Percival Bailey. On his return to Belo Horizonte, he became associate professor in 1955 and chair of Neurology and Neurosurgery in 1962. The period of Albernaz's chairmanship was characterized by neurology being practiced by neurosurgeons. When he returned to the USA in 1968, one of his assistants, Gilberto Belisário Campos (1933-2013) became interim chief of Neurology and Neurosurgery. In 1981, Campos received the full professorship and became chair of Neurology and Neurosurgery. Belisário's alma mater was also the Federal University of Minas Gerais School of Medicine. He trained as a neurosurgeon and neurologist in Madison, Wisconsin, and was the first Brazilian neurologist to become board certified by the American Academy of Neurology. Despite his dual background, he was primarily a neurologist - as a matter of fact, a very gifted clinician - who led the neurology of Minas Gerais into an era of independence and autonomy $y^{1,3}$.

\section{NEUROLOGY IN PERNAMBUCO}

Ulysses Pernambucano de Melo Sobrinho (1892-1943) graduated from the Faculty of Medicine of Rio de Janeiro in 1912 and was the founder of the Pernambucan Neuropsychiatric School, a part of the Faculty of Medicine of Pernambuco that was founded in 1920. Ulysses was an assistant professor of the Neurological and Psychiatric Clinic, professor of neuropsychiatric semiology and professor of the Neurological Clinic of the current Health Sciences Center of the Federal University of Pernambuco. He was the author of several works, especially in the areas of neuropsychiatry and anthropology. He created (and was the first leader of) Neurobiology, the oldest neuropsychiatric magazine in Latin America, and was the founder of the League of Mental
Hygiene and the North-east Society of Neurology, Psychiatry and Mental Hygiene ${ }^{3}$.

\section{NEUROLOGY IN PARANÁ}

At the Faculty of Medicine of the University of Paraná (founded in 1914 and officially recognized in 1922), the neurology school began in 1924 with the appointment of Dr. Octavio da Silveira (1895-1966) to run the Department of Neurology. Dr. Silveira was born in the Rio Grande do Sul and was a disciple of Austregésilo. As a member of the Brazilian Academy of Neurology, Silveira participated in its foundation in Rio de Janeiro in 1962, as well as being a part of the organization committee of its first scientific meeting, held in Curitiba, Paraná, in 1963. He taught for 46 years and was succeeded by Rubens de Lacerda Manna (1914-1995) in $1966^{3}$.

\section{NEUROLOGY IN THE RIO GRANDE DO SUL}

The School of Medicine in Rio Grande do Sul (1898) had professor Celso Machado de Aquino (1912-1982) as its first prominent figure in neurology. In 1938, he was appointed professor of the Neurological Clinic, replacing Fábio de Barros. He was named the director of the Department of Neurology at the Federal University of Rio Grande do Sul in 1960. In 1969, he founded the Neurology Institute of Santa Casa and remained its director until his death. In 1965, he became a titular professor and head of the Department of Neurology of the Catholic College of Medicine of Porto Alegre. He was also a leading figure in the foundation of the Brazilian Academy of Neurology, of which he was president from 1968 to $1970^{3,14}$.

Among the global trends of postmodern society that characterize neurology in Brazil today are the following: the reformulation of higher education, the cessation of the appointment of chairs, the primacy of the departments, the greater representation of women in medicine and the incorporation of new therapeutic techniques and diagnostic resources for traditional anatomo-clinical methods.

\section{CONCLUSION}

The aim of this article was to provide a brief overview of the history of the first neurological schools in Brazil. The neurology we see today is the result of a long trajectory and may be attributed to scientists from several countries and, in particular, Brazilian researchers, who devoted their lives to the consolidation of this medical specialty. Neurology is certainly a continuously changing field and has always adapted to new advances and discoveries, and it is an honor for the authors to pay homage to their pioneers, and look forward to the future of Brazilian neurology. 


\section{References}

1. Gusmão SS. [History of neurology in Belo Horizonte, Brazil] [Internet]. Arq Neuropsiquiatr. 1998 Mar;56(1):146-9. Portuguese. https://doi.org/10.1590/S0004-282X1998000100027

2. Gomes MM, Cavalcanti JL, Engelhardt E. French school of neurology in the 19th and first half of the 20th century, and its influence in Brazil. Arq Neuropsiquiatr. 2013 Oct;71(10):818-21. https://doi.org/10.1590/0004-282X20130129

3. Gomes MM, Teive HA. História da neurologia brasileira: cinquentenário da Academia Brasileira de Neurologia: centenário da neurologia brasileira. São Paulo: Academia Brasileira de Neurologia; 2012.

4. Gomes MM. Marcos históricos da neurologia. Rio de Janeiro: Científica Nacional; 1997.

5. Teive HA, Almeida SM, Arruda WO, Sá DS, Werneck LC. Charcot and Brazil. Arq Neuropsiquiatr. 2001 Jun;59(2a):295-9. https://doi.org/10.1590/S0004-282X2001000200032

6. Teive HG, Sá D, Silveira Neto O, Silveira OA, Werneck LC. Professor Antonio Austregésilo. The pioneer of neurology and of the study of movement disorders in Brazil. Arq Neuropsiquiatr. 1999 Sep;57(3B):898-902. Portuguese. https://doi.org/10.1590/S0004-282X1999000500030

7. Kakitani FT, Collares D, Kurozawa AY, Lima PM, Teive HA. How many Babinski's signs are there? Arq Neuropsiquiatr. 2010 Aug;68(4):662-5. https://doi.org/10.1590/S0004-282X2010000400037

8. ANeuro. História da ANeuro. Belo Horizonte: ANeuro; 2014 [cited 2018 Nov 6]. Available from: http://academicaneuro.wixsite.com/ aneuro/about-us

9. Faculdade de Medicina da Bahia. Histórico. Salvador: Faculdade de Medicina da Bahia [cited 2018 Jul 7]. Available from: http://www. fameb.ufba.br/institucional/historico
10. Canelas HM. Breve histórico do Departamento de Neurologia da Faculdade de Medicina da Universidade de São Paulo durante o período 1939-1969. Arq Neuropsiquiatr. 1969 Dec;27(4):353-60. https://doi.org/10.1590/S0004-282X1969000400015

11. Ferraz HB, Neves AC. Neurology at Escola Paulista de Medicina (1933-1995). From Fausto Guerner to José Geraldo Camargo Lima [Internet]. Arq Neuropsiquiatr. 2015 Feb;73(2):166-9. https://doi.org/10.1590/0004-282X20140211

12. Motoyama, S. Prelúdio para uma história: ciência e tecnologia no Brasil. São Paulo: Edusp; 2004.

13. Spina-França Netto A. Oswaldo Lange e Arquivos de Neuro-Psiquiatria. In: Reimão R, editor. História da neurologia no Brasil. São Paulo: Lemos; 1999. p. 53-67.

14. Academia Brasileira de Neurologia - ABN. Quem somos [cited 2018 Nov 6]. Available from: https://www.portalabn.org/institucionalquem-somos

15. Faculdade de Ciências Médicas da Santa Casa de São Paulo. Histórico. [cited 2019 Jun 09]. Available from: https://fcmsantacasasp.edu.br/fcmscsp/

16. Cabral Filho G, Gusmão S, Silveira RL. [Egas Moniz and the Brazilian neurosurgery]. Arq Bras Neurocir. 2000;19(3):136-9. Portuguese. https://doi.org/10.1055/s-0038-1623299

17. Del Bem CM, Lison MP, Marturano EM. Departamento de Neurologia, Psiquiatria e Psicologia Médica. Med Ribeirão Preto. 2002;35(3):313-20. https://doi.org/10.11606/issn.2176-7262.v35i3p313-320

18. Faculdade de Ciências Médicas. Departamento de Neurologia. Histórico.[cited 2018 Sep 19]. Available from: https://www.fcm. unicamp.br/fcm/departamento-de-neurologia

19. Nava P. Beira mar. Rio de Janeiro: José Olympio; 1978.

20. Nava P. Galo das trevas. Rio de Janeiro: Ateliê; 2003. 